\title{
Effect of Drying Methods and Storage on the Physicochemical Properties of Okra
}

\section{Eze $\mathrm{JI}^{1 *}$ and Akubor $\mathrm{PI}^{2}$}

${ }^{1}$ National Centre for Energy Research and Development, University of Nigeria, Nsukka, Nigeria ${ }^{2}$ Department of food Science and Technology, University of Nigeria, Nsukka, Nigeria

\begin{abstract}
The effects of blanching and drying methods on the physicochemical properties of okra (lady's fingers) were studied. Fresh sliced "okra" used for the study was divided into two portions. One portion was steam-blanched, oven-dried and packaged in black polyethylene bag and stored in a dark cool place and over hearth for 8 weeks. The second portion was steam-blanched, sun-dried, packaged and stored as described for the oven-dried sample. The fresh and stored samples were analyzed for their proximate composition and mineral contents. The results showed that blanching followed by oven or sundrying decreased the moisture, vitamins $\mathrm{A}$ and $\mathrm{C}$ concentrations but increased the, protein, ash, iron, zinc, calcium and magnesium contents of the okra fruits. However, the ovendried okra samples were higher in these constituents than the sun-dried okra sample. The viscosity and moisture content of the samples decreased during storage, regardless of the storage conditions. However, the blanched and oven-dried okra samples packaged in air-tight container and stored in dark, cool place, retained more of its chemical constituents and viscosity than the other stored samples.
\end{abstract}

Keywords: Blanching okra; Oven- drying; Sun drying; Viscosity

\section{Introduction}

Okra is a widely consumed cultivated vegetable in tropical and subtropical countries. The most important okra producing countries are India, Nigeria, Pakistan, Ghana and Egypt. This vegetable is more famously known by its rows of tiny seeds and slimy or sticky texture when cut open. It is easy to cultivate, suited to regions with moderate rainfall and is normally grown during the summer [1]. Okra is also a crop of significant nutritional value that contains a high percentage of water, averaging $85 \%$, fat and protein in a small and varying amount, a fair proportion of carbohydrates which are present as cellulose, starch in small quantity and sugar [2]. It also contains non-cellulose, nonstarch, polysaccharides [2]. It is a source of protein, vitamins $\mathrm{C}$ and $\mathrm{A}$, iron and calcium [3] and dietary fibre [4]. The most extensive use of okra is in the home garden, on the small farm and at large agricultural enterprise level [1]. It is used in the fresh state and the product may be processed (by drying or blanching before drying) and then preserved for later use. In Nigeria, particularly, the western part, okra is commonly used for making soup (as a thickener), cooking of yam etc. Okra contains large quantities of glycans, which are responsible for the viscosity of the aqueous suspension [5] and the stringy, gum-like consistency that is particularly desirable in soups. The okra pod which is quite slimy even after cooking is most often used in stews, soups and gravis, giving a thickening effect in soups [6]. Sliminess property of the okra fruit is of great importance to its acceptability and food value to consumers [7]. The more viscous or slimy okra is better and is rated as a food thickener. Okra mucilage is suitable for medicinal and industrial applications. It has medically found application as a plasma replacement or blood volume expander. Industrially, okra mucilage is usually used to glace certain papers and also useful in confectionery among other uses [8]. Okra is highly perishable because of its high moisture content and respiratory activities; thus, it is necessary to preserve the commodity. Sometimes, processing of okra involves blanching, which is a heat treatment, given to vegetables to limit or put a stop to both enzymatic and microbial activities.
Drying is the traditional and oldest method of processing okra to reduce the water activity and improve the keeping quality [2]. Drying may be achieved by sun or using hot-air oven. Industrial and home usage of oven is increasing and the primary use in the home is reheating while tempering, cooking, drying and pasteurization are the main applications in the industry [9].

Dehydrated foods and the dried components of many formulated or manufactured foods are now common articles of commerce and drying is becoming a standard processing operation. Its technology is now rather well defined and it is carried out in well tested types and sizes of equipment to produce billions of pounds of dry product annually [10].

In Nigeria, as in many other countries of the tropics, vegetables are very abundant immediately after the early rains but become scarce later in the rainy season and more so in the dry season [3]. To this effect, there is need for okra to be dried, processed (for the purpose of preservation) and stored for later use. This study therefore, was carried out to determine the effects of processing (blanching, oven and sun drying) and storage on the selected properties of dehydrated okra.

\section{Materials and Methods}

The okra variety used for this study was lady's finger. Green fresh okra pods (Abelmoscus esculentus-Lady's fingers) were procured from Ogige community market, in Nsukka town, Enugu State, Nigeria.

*Corresponding author: Eze Jl, National Centre for Energy Research and Development, University of Nigeria, Nsukka, Nigeria, Tel: +2348063285864; E-mail: ikejon85@yahoo.com

Received May 19, 2012; Accepted July 31, 2012; Published August 04, 2012

Citation: Eze JI, Akubor PI (2012) Effect of Drying Methods and Storage on the Physicochemical Properties of Okra. J Food Process Technol 3:177. doi:10.4172/2157-7110.1000177

Copyright: (c) 2012 Eze Jl, et al. This is an open-access article distributed unde the terms of the Creative Commons Attribution License, which permits unrestricted use, distribution, and reproduction in any medium, provided the original author and source are credited. 


\section{Sample preparation}

The okra fruits were sorted, washed, stumps trimmed off (with a sharp knife) weighed $(1,300 \mathrm{~g})$ and then divided into two portions of equal size. Each portion $(650 \mathrm{~g})$ was weighed and cut into slices (using a sharp knife), steam-blanched $\left(95^{\circ} \mathrm{C}\right.$ for 5 minutes) and cooled for 10 minutes at room temperature. One portion of the blanched samples was dried in the conventional oven at $50^{\circ} \mathrm{C}$ for 17 hours and the other portion was sun-dried for 3 days at $29-30^{\circ} \mathrm{C}$ and $60 \%$ relative humidity. The resulting steam-blanched and oven-dried okra was further divided into eight portions where four (4) portions were stored over a heat chamber and the remaining four (4) portions were wrapped in black low density polythene bags kept in an air-tight container (custard bucket) and stored in an enclosed cabinet (60\% relative humidity for 8 weeks). The same treatment was given to the sun-dried sample. The dry samples were analysed before storage (at zero week) and after storage (at $8^{\text {th }}$ week) for proximate composition, viscosity, minerals $(\mathrm{Ca}, \mathrm{Mg}$, $\mathrm{Fe}$ and $\mathrm{Zn}$ ) and vitamins (A and $\mathrm{C}$ ).

\section{Analytical methods}

Moisture was determined by hot oven (Gallenkamp BS Oven,UK) drying at $105^{\circ} \mathrm{C}$ to constant weight [11]. Ash, protein (Nx6.25), crude fibre and crude protein (solvent extraction) were determined by the AOAC [12] methods, 14.085, 14.086, 14.087 and 14.089, respectively. Carbohydrate was calculated by difference $(100-(\%$ protein $+\%$ ash + $\%$ moisture + fat $+\%$ crude protein). Vitamin $C$ was determined by the 2, 6-dichlorophenol - indophenols dye method following the AOAC (2010) method. Iron, Zinc, Calcium and Magnesium were measured using atomic absorption spectrophotometer (model Pye Unican SP 191, Cambridge as described by AOAC (2010)). For the determination of viscosity, $10 \mathrm{gm}$ of okra powder was mixed with $100 \mathrm{ml}$ of distilled water. The viscosity of the slurry at ambient temperature $\left(30 \pm 2^{\circ} \mathrm{C}\right)$ using Brookfield Viscometer (LV-8, England) using appropriate spindle as described by the AOAC [12] method was determined.

\section{Results and Discussion}

The proximate composition of the okra samples ffresh sample (FS), blanched and oven-dried sample (BOS); and blanched and sun-dried sample (BSS)\} before storage is shown in Table 1. Drying reduced the moisture content markedly with blanched oven-dried sample (BOS) having the lowest moisture content of $10.6 \%$ while blanched sun dried sample (BSS) had $15.36 \%$ moisture content. The higher moisture in sun dried sample was probably due to the high and controlled temperature in the oven tray dryer $\left(50^{\circ} \mathrm{C}\right)$ relative to the sun peak temperature of $29^{\circ} \mathrm{C}$ ). However, there were increases in the crude protein, contents of the dried samples. This may be as a result of drying that resulted in the corresponding increase of dry matter contents due to concentration of soluble solids. The decreases in the crude fibre, crude fat and crude carbohydrate contents of the dried samples on dry weight basis could be linked to the increases in the other components.

The micronutrient contents of the okra samples before storage are shown in Table 2. There was a decrease in vitamin $\mathrm{C}$ content of the treated okra samples. This could be attributed to the fact that vitamin $\mathrm{C}$ is water soluble and may have been easily lost by leaching. It is also heat labile with or without the presence of oxygen. The oven temperature would have slightly increased oxidation of vitamin $\mathrm{C}$ relative to sun drying. Vitamin A did not increase during the drying of the samples. Fellows [13] reported that vitamin $A$ is a fat soluble vitamin which is mostly contained within the dry matter of the food and it is not

\begin{tabular}{|c|c|c|c|}
\hline Composition(\%) & FS & BOS & BSS \\
\hline Moisture & $89.09^{\mathrm{c}} \pm 0.01$ & $10.64^{\mathrm{c}} \pm 0.01$ & $15.36^{\mathrm{b}} \pm 0.03$ \\
\hline Crude fibre & $8.34^{\mathrm{a}} \pm 0.02$ & $6.22^{\mathrm{b}} \pm 0.02$ & $6.06^{\mathrm{b}} \pm 0.02$ \\
\hline Crude protein & $20.7^{\mathrm{a}} \pm 0.07$ & $25.12^{\mathrm{c}} \pm 0.01$ & $125.34^{\mathrm{b}} \pm 0.02$ \\
\hline Crude fat & $4.12^{\mathrm{a}} \pm 0.03$ & $2.44^{\mathrm{c}} \pm 0.02$ & $1.91^{\mathrm{b}} \pm 0.03$ \\
\hline Ash & $7.7^{\mathrm{a}} \pm 0.04$ & $10.53^{\mathrm{c}} \pm 0.02$ & $10.05^{\mathrm{b}} \pm 0.10$ \\
\hline Carbohydrate & $59.85^{\mathrm{a}} \pm 0.01$ & $55.68^{\mathrm{c}} \pm 0.01$ & $56.63^{\mathrm{b}} \pm 0.03$ \\
\hline
\end{tabular}

Values are means of three (3) replications \pm standard deviation. Means within a row with the same superscript were not significantly different $(P<0.05)$. FS, fresh sample, BOS, Blanched oven-dried sample, BSS, blanched sun dried sample. Means in brackets are in dry weight basis.

Table 1: Proximate composition of fresh and treated okra samples.

\begin{tabular}{|c|c|c|c|}
\hline \multicolumn{4}{|c|}{ Samples } \\
\hline Parameters & FS & BOS & BSS \\
\hline Vitamin A $(\mu \mathrm{g})$ & $55.9^{\mathrm{b}} \pm 0.05$ & $6.08^{\mathrm{b}} \pm 0.01$ & $5.96^{\mathrm{c}} \pm 0.02$ \\
\hline Vitamin C $(\mathrm{mg} / 100 \mathrm{~g})$ & $71.3^{\mathrm{a}} \pm 0.01$ & $5.49^{\mathrm{b}} \pm 0.02$ & $5.67^{\mathrm{b}} \pm 0.01$ \\
\hline Iron $(\mathrm{mg} / 100 \mathrm{~g})$ & $3.57^{\mathrm{a}} \pm 0.01$ & $1.29^{\mathrm{b}} \pm 0.01$ & $0.69^{\mathrm{b}} \pm 0.01$ \\
\hline Zinc $(\mathrm{mg} / 100 \mathrm{~g})$ & $15.5^{\mathrm{a}} \pm 0.01$ & $3.76^{\mathrm{b}} \pm 0.01$ & $3.13^{\mathrm{b}} \pm 0.01$ \\
\hline Calcium $(\%)$ & $57.1^{\mathrm{a}} \pm 0.01$ & $19.28^{\mathrm{c}} \pm 0.01$ & $12.02^{\mathrm{c}} \pm 0.02$ \\
\hline Magnesium $(\%)$ & $21.6^{\mathrm{a}} \pm 0.01$ & $5.91^{\mathrm{b}} \pm 0.01$ & $4.75^{\mathrm{c}} \pm 0.02$ \\
\hline
\end{tabular}

Values are means of three (3) replications \pm standard deviation. Means within a row with the same superscript were not significantly different $(P<0.05)$. FS, fresh sample,BOS, Blanched oven-dried sample, BSS, blanched sun dried sample.

Table 2: Micronutrients of fresh and treated okra samples.

concentrated during drying. The decreases observed in the values of vitamin $\mathrm{A}$ in the oven and sun-dried samples could be attributed to heating effect with sun drying exerting greater effect. Increases occurred in the mineral contents ( $\mathrm{Fe}, \mathrm{Ca}, \mathrm{Zn}$ and $\mathrm{Mg}$ ) of the dried samples due to concentration effect.

\section{The effect of storage on moisture and viscosity}

The effect of storage on moisture content and viscosity of okra samples are shown in Table 3. The moisture content of the samples for all the treatments before storage ranged from 10.64-9.72\% (dry weight basis) and viscosity varied from 1,500-1,600 cp, with sample A (fresh sample) having the highest values of moisture content and viscosity. During storage at $60 \%$ relative humidity, the stored samples showed varying degrees of moisture loss that depended on the temperature of the storage environment $\left(29-30^{\circ} \mathrm{C}, 60-65 \%\right.$ relative humidity). The moisture loss corresponded with decrease in the viscosity of all the samples on storage. This was in agreement with the report of Potter and Hotchkiss [14] who reported that the rheological properties of starch and gums in food system may be altered by heat and the hydrophilic properties of such foods may also be affected.

\section{Proximate composition as affected by storage}

Table 4 shows the proximate composition of the okra samples after storage under different condition for 8 weeks. The moisture content decreased during storage of all the samples. The oven-dried samples stored in a dark, cool place and oven-dried sample stored over a hearth had the same moisture contents which were lower when compared with other treated samples. When the relative humidity of the storage environment is low at high temperature, there would be loss of moisture from the samples to the surrounding; thereby reducing the moisture content of the samples. Changes in crude fibre content of the samples subjected to different storage conditions were not significant 
Citation: Eze JI, Akubor PI (2012) Effect of Drying Methods and Storage on the Physicochemical Properties of Okra. J Food Process Technol 3:177. doi:10.4172/2157-7110.1000177

Page 3 of 4

\begin{tabular}{|c|c|c|c|c|c|c|c|c|c|c|}
\hline \multicolumn{11}{|c|}{$\begin{array}{c}\text { Parameters } \\
\text { Storage periods }\{(\text { Weeks })\end{array}$} \\
\hline \multirow[t]{2}{*}{ SAMPLES } & \multicolumn{2}{|c|}{0} & \multicolumn{2}{|c|}{2} & \multicolumn{2}{|c|}{ k 4} & \multicolumn{2}{|c|}{6} & \multicolumn{2}{|r|}{8} \\
\hline & $\mathrm{MC}(\%)$ & $(\mathrm{cp})$ & $\mathrm{MC}(\%)$ & $(\mathrm{cp})$ & $\mathrm{MC}(\%)$ & $(\mathrm{cp})$ & MC (\%) & (cp) & MC (\%) & (cp) \\
\hline FS & $89.09^{c} \pm 0.01$ & $1600^{a} \pm 0.00$ & & & & & & & & \\
\hline BOS & $10.64^{a} \pm 0.01$ & $1500^{b} \pm 0.58$ & & & & & & & & \\
\hline BSS & $5.36^{b} \pm 0.03$ & $1550^{b} \pm 0.00$ & & & & & & & & \\
\hline $\begin{array}{l}\text { BOS (Stored in a dark- } \\
\text { cool dry place) }\end{array}$ & & & $9.07^{b} \pm 0.01$ & $1450^{\mathrm{b}} \pm 1.53$ & $786^{b} \pm 0.02$ & $1350^{\mathrm{a}} \pm 1.15$ & $5.94^{\mathrm{b}} \pm 0.03$ & $1300^{\mathrm{ab}} \pm 1.53$ & $5.12^{\mathrm{a}} \pm 0.03$ & $1250^{\mathrm{b}} \pm 2.00$ \\
\hline $\begin{array}{l}\text { BOS (Stored over a } \\
\text { hearth) }\end{array}$ & & & $8.94^{a} \pm 0.05$ & $1400^{\mathrm{a}} \pm 2.08$ & $7.62^{\mathrm{a}} \pm 0.02$ & $1300^{\mathrm{a}} \pm 0.58$ & $5.78^{a} \pm 0.01$ & $1280^{\mathrm{b}} \pm 0.29$ & $5.12^{\mathrm{a}} \pm 0.02$ & $1250^{\mathrm{b}} \pm 2.65$ \\
\hline $\begin{array}{l}\text { BSS (Stored in a dark- } \\
\text { cool dry place) }\end{array}$ & & & $15.12^{d} \pm 0.02$ & $1550^{\mathrm{ab}} \pm 1.53$ & $14.67^{d} \pm 0.02$ & $1500^{\mathrm{b}} \pm 1.15$ & $11.37^{\mathrm{d}} \pm 0.01$ & $1320^{\mathrm{a}} \pm 1.00$ & $9.33^{c} \pm 0.02$ & $1350^{\mathrm{a}} \pm 1.00$ \\
\hline $\begin{array}{l}\text { BSS (Stored over a } \\
\text { hearth) }\end{array}$ & & & $15.01^{c} \pm 0.02$ & $1500^{\mathrm{ab}} \pm 5.51$ & $14.39^{c} \pm 0.03$ & $1310^{\mathrm{a}} \pm 3.79$ & $11.28^{c} \pm 0.02$ & $1290^{\mathrm{b}} \pm 0.58$ & $9.25^{\mathrm{b}} \pm 0.01$ & $1200^{b} \pm 4.73$ \\
\hline
\end{tabular}

Values are means of three (3) replications \pm standard deviation. Means within a row with the same superscript were not significantly different (P<0.05). FS, fresh sample BOS, Blanched oven-dried sample, BSS, blanched sun dried sample, MC, moisture content.

Table 3: Effect of storage on moisture and viscosity of okra samples.

\begin{tabular}{|c|c|c|c|c|}
\hline \multicolumn{5}{|c|}{ Samples } \\
\hline Parameters (\%) & BOS (stored in a dark cool place) & BOS (stored over a hearth) & BSS (stored in a dark coo place) & BSS (stored over a hearth) \\
\hline Moisture & $5.12^{\mathrm{b}} \pm 0.02$ & $5.12^{\mathrm{b}} \pm 0.03$ & $9.33^{\mathrm{a}} 0 \pm .02$ & $9.25^{\mathrm{a}} \pm 0.03$ \\
\hline Crude fibre & $5.75^{a} \pm 0.02$ & $5.24^{\mathrm{a}} \pm 0.01$ & $5.62^{\mathrm{a}} \pm 0.01$ & $5.63^{a} \pm 0.01$ \\
\hline Crude protein & $21.12^{\mathrm{a}} \pm 0.02$ & $19.28^{\mathrm{b}} \pm 0.01$ & $17.46^{c} \pm 0.03$ & $17.11^{\mathrm{c}} \pm 0.01$ \\
\hline Crude fat & $1.72^{\mathrm{a}} \pm 0.03$ & $1.72^{\mathrm{a}} \pm 0.03$ & $1.18^{\mathrm{b}} \pm 0.02$ & $1.12^{\mathrm{b}} \pm 0.02$ \\
\hline Total ash & $9.29^{\mathrm{a}} \pm 0.01$ & $8.88^{b} \pm 0.01$ & $9.05^{\mathrm{a}} \pm 0.03$ & $9.05^{\mathrm{a}} \pm 0.03$ \\
\hline Carbohydrate & $62.12^{\mathrm{d}} \pm 0.01$ & $63.38^{c} \pm 0.02$ & $66.68^{a} \pm 0.02$ & $67.28^{\mathrm{a}} \pm 0.00$ \\
\hline
\end{tabular}

Values are means of three (3) replications \pm standard deviation. Means within a row with the same superscript were not significantly different $(\mathrm{P}<0.05)$. $\mathrm{FS}$, fresh sample, BOS, Blanched oven-dried sample, BSS, blanched sun dried sample.

Table 4: Effects of storage on the proximate composition of blanched oven-dried and sun-dried okra samples.

\begin{tabular}{|c|c|c|c|c|}
\hline \multicolumn{5}{|c|}{ Samples } \\
\hline Parameters (\%) & $\begin{array}{l}\text { BOS (stored in a dark cool } \\
\text { place) }\end{array}$ & BOS (stored over a hearth) & BSS (stored in a dark coo place) & BSS (stored over a hearth) \\
\hline $\begin{array}{l}\text { itamin A (ug) } \\
\text { Vitamin }(\mathrm{mg} / 100 \mathrm{~g})) \\
\text { Iron }(\mathrm{mg} / 100 \mathrm{~g}) \\
\text { Zinc }(\mathrm{mg} / 100 \mathrm{~g}) \\
\text { Calcium }(\%) \\
\text { Magnesium }(\%)\end{array}$ & $\begin{array}{c}5.05^{\mathrm{a}} \pm 0.02 \\
4.42^{\mathrm{a}} \pm 0.00 \\
1.18^{\mathrm{a}} \pm 0.02 \\
3.44^{\mathrm{a}} \pm 0.04 \\
19.92^{\mathrm{a}} \pm 0.01 \\
3.99^{\mathrm{a}} \pm 0.01\end{array}$ & $\begin{array}{c}5.05^{\mathrm{a}} \pm 0.00 \\
2.55^{\mathrm{c}} \pm 0.02 \\
1.09 \pm 0.03 \\
3.29^{\mathrm{a}} \pm 0.03 \\
17.80^{\mathrm{b}} \pm 0.01 \\
3.90^{\mathrm{a}} \pm 0.01\end{array}$ & $\begin{array}{c}2.93^{\mathrm{c}} \pm .002 \\
3.74^{\mathrm{b}} \pm 0.03 \\
0.63^{\mathrm{b}} \pm 0.01 \\
2.71^{\mathrm{b}} \pm 0.02 \\
11.03^{\mathrm{c}} \pm 0.00 \\
3.68^{\mathrm{a}} \pm 0.02\end{array}$ & $\begin{array}{c}3.10^{\mathrm{b}} \pm 0.02 \\
2.60^{\mathrm{c}} \pm 0.03 \\
2.61^{\mathrm{b}} \pm 0.01 \\
2.62^{\mathrm{b}} \pm 0.02 \\
10.68^{\mathrm{d}} \pm 0.02 \\
3.65^{\mathrm{a}} \pm 0.02\end{array}$ \\
\hline
\end{tabular}

Values are means of three (3) replications \pm standard deviation. Means within a row with the same superscript were not significantly different $(P<0.05)$. FS, fresh sample, BOS, Blanched oven-dried sample, BSS, blanched sun dried sample.

Table 5: Effects of storage on the micro-nutrients of blanched oven-dried and sun-dried okra samples.

$(\mathrm{P}>0.05)$. Fibre in all the samples differed significantly $(\mathrm{P}>0.05)$ from the initial values before storage which ranged from 5.13-5.56\%. Crude fibre was not significantly $(\mathrm{P}>0.05)$ affected by blanching and drying as well as storage. However, the slight changes observed may be due to variation in processing condition. Oven dried samples that were stored in a dark cool dry place had the highest value of crude fibre (5.46\%). Crude protein contents decreased during storage. This may be attributed to Maillard browning that probably occurred during protein hydrolysis. Crude fat content decreased during storage, values ranged from $1.02 \%-1.63 \%$. Values were relatively higher in oven-dried sample $(1.63 \%)$ stored in a dark cool dry place than other treated samples (with the exception of oven- dried sample stored over hearth. Total ash contents of all the samples ranged from $8.11 \%-8.81 \%$. The total ash content of the oven-dried sample (8.81\%) stored in a dark, cool dry place was higher than those of the other treated samples. These changes were not expected since ash is stable to heat, air and storage conditions. However, the changes that occurred may be attributed to variations in processing conditions. The results showed that ovendried sample had relatively higher carbohydrate value than sun-dried sample. These changes were expected due to changes that occurred on other proximate compositions since carbohydrate was obtained by difference. Both the oven and sun dried samples stored over a heart had higher carbohydrate contents than the other samples.

\section{Micronutrients}

Table 5 shows the micronutrient contents of the samples after storage for 8 weeks. Changes in the values of minerals ( $\mathrm{Fe}, \mathrm{Zn}, \mathrm{Ca} \&$ $\mathrm{Mg}$ ) of all the samples during storage were not expected since minerals 
Citation: Eze Jl, Akubor PI (2012) Effect of Drying Methods and Storage on the Physicochemical Properties of Okra. J Food Process Technol 3:177. doi:10.4172/2157-7110.1000177

are generally stable during storage (Owoeye et al. 1978). However, the slight changes that occurred in the values may be attributed to slight changes that occurred in the ash content of all the samples. Vitamin C content decreased during storage and ranged from $2.36 \%-4.19 \%$. Values were relatively higher in oven-dried (4.19\%) sample stored in a dark cool place than in other treated samples. This may be due to absence of light and air that may ordinarily cause oxidation of vitamin C. Vitamin A content decreased during storage, values ranged from $2.66 \%-4.79 \%$. Values were relatively higher in oven-dried sample $(4.79 \%)$ stored in a dark cool place than other treated samples. This may be due to absence of light and air that could cause oxidation which can lead to depletion of the vitamin.

\section{Conclusion}

The results of this study showed that blanching had variable effects on the dry matter contents of processed okra samples. It helped to inactivate enzymes and micro organisms in the okra and also facilitated moisture loss during drying. Drying reduced the moisture content which resulted in the corresponding increase in dry matter content of protein, ash and minerals $(\mathrm{Zn}, \mathrm{Ca}, \mathrm{Mg}$ and $\mathrm{Fe}$ ) in the okra. Storage of the oven-dried okra samples in air-tight container in a dark cool dry place retained the physicochemical properties of the okra than the other treated samples.

\section{References}

1. Martin FW, Ruberte R (1978) Vegetables for the hot humid tropics, Part 2. Okra Abelmoschus esculentus Horticulturist and Agricultural Research, Mayagues Institute of Tropical Agriculture, Agricultural Research, Science and Education Administration, USDA, Mayaguez, PR 00708.

2. Fellows P (2000) Food processing technology: Principles and practice. Woodhead Publishers, London.
3. Ihekoronye Al, Ngoddy PO (1985) Integrated Food Science and Technology for the Tropics. Macmillan Education Ltd, London.

4. Adom KK, Dzogbefia VP, Ellis WO, Simpson BK (1996) Solar drying of okraeffects of selected package materials on storage stability. Food Res Intl 29: 589-593.

5. Owoeye Al, Caurie MC, Allagheny NN, Onyezili FN (1990) Chemical and physical parameters affecting the viscosity of mixed okra and tomato homogenate. J Sci Food Agric 53: 283-286.

6. Janick J, Schery RW, Woods FW, Ruttan VW (1981) Plant Science. An Introduction to World Crops. (3rd edn) Freeman \& Comp.

7. Uzo JO, Ojiako GU (1980) A physical method for measuring okra fruit quality J Food Sci 45: 390-391.

8. Markose BL, Peter KV (1990). Review of research on vegetable and Tuber crops: Okra. Kerala Agricultural University Press, Kerala 16.

9. Decareau RV (1985) Microwaves in the Food Processing Industry. Academic Press, New York.

10. Van Arsdel WB (1965) Food dehydration: Recent advances and unsolved problem. J Food Sci Technol. 58: 484-486.

11. Pearson D (1976) The chemical analysis of foods. (7thedn), Churchill Livingstone Edinburgh. 92-94.

12. AOAC (2000). Official Methods of Analysis Association of Official Analytica Chemists.(16thedn), Washington DC.

13. Fellows PS (1998). Food Processing Technology: Principles and Practice.Ellis Horwood limited,West Sussex, England.31-35, 197-208.

14. Potter NN, Hotchkiss JH (1996) Food Sci. CBS Publishers,New Delhi 200-238

15. Aworh OC, Olorunda AO, Akibo O (1980) Quality attributes of frozen okra as influenced by processing and storage. J Food Technol 15: 429-433. 